\title{
Winning and losing in the creative industries: an analysis of creative graduates' career opportunities across creative disciplines
}

Article

Accepted Version

Comunian, R., Faggian, A. and Jewell, S. (2011) Winning and losing in the creative industries: an analysis of creative graduates' career opportunities across creative disciplines. Cultural Trends, 20 (3-4). pp. 291-308. ISSN 1469-3690 doi: https://doi.org/10.1080/09548963.2011.589710 Available at https://centaur.reading.ac.uk/24832/

It is advisable to refer to the publisher's version if you intend to cite from the work. See Guidance on citing.

To link to this article DOI: http://dx.doi.org/10.1080/09548963.2011.589710

Publisher: Taylor \& Francis

All outputs in CentAUR are protected by Intellectual Property Rights law, including copyright law. Copyright and IPR is retained by the creators or other copyright holders. Terms and conditions for use of this material are defined in the End User Agreement. 


\section{CentAUR}

Central Archive at the University of Reading

Reading's research outputs online 


\title{
Winning and losing in the creative industries. An analysis of creative graduates' career opportunities across creative disciplines
}

\begin{abstract}
Following earlier work looking at overall career difficulties and low economic rewards faced by graduates in creative disciplines, the paper takes a closer look into the different career patterns and economic performance of 'bohemian graduates' across different creative disciplines, namely Advertising, Architecture, Crafts, Design, Film and Television, Fine Art, Music, Performing Arts, Technology and Writing and Publishing. While it is widely acknowledge in the literature that careers in the creative field tends to be unstructured, often relying on part-time and temporary work as well as on low wages, our knowledge of how these characteristics differs across the creative industries and occupational sectors is very limited. The paper therefore explores the different trajectory and career patterns experienced by graduate in different creative disciplinary fields and their ability to enter creative occupation and higher level of salary. Data from the Higher Education Statistical Agency (HESA) are presented, articulating a complex picture of the reality of finding a creative occupation for creative graduates. While students of some disciplines struggle to find full-time work and to enter the creative economy, for other students in different creative fields full-time occupation is a norm. While most creative graduates show lower salaries than other graduates, for some disciplines the wage gap is minimal, while for others it consistent and extreme. Geography plays a crucial role also in offering graduates opportunities in creative occupations and higher salaries. The findings are contextualised in the New Labour cultural policy framework and the hype surrounding the creative industries that has characterised the last decade and conclusions are draw on whether the creative industries policy construct has hidden a very problematic reality of winners and losers in the creative economy.
\end{abstract}




\section{Introduction}

It is widely acknowledged in the literature that one of the impacts of New Labour's cultural policy in UK has been a growing hype and positive representation of creative and cultural occupations (Banks \& O'Connor, 2009). When the New Labour policies came into place, they built on the changing economic dynamics of contemporary society embracing the new paradigm of post-industrial, flexible and knowledge-based production. In this broader framework, all knowledge driven industries were celebrated (Banks \& Hesmondhalgh, 2009) but more than any others the creative industries. These industries that were defined as "hav[ing] their origins in individual creativity, skills and talent" (DCMS, 1998) were presented as the new flagship of the UK economy. However, together with the many policy documents supporting the New Labour re-positioning of the UK economy in the creative, innovative, knowledge-base economy (DCMS, 1999a, 1999b, 2001, 2003), some academic studies showed the shortcomings and limitations of the sector pointing out the very limited London-centric reach of its impact (Knell \& Oakley, 2007; Pratt, 1997) and the real extent of its growth and expansion (Taylor, 2006).

As Banks and Hesmondhalgh (2009) highlight, one of the weakest points of New Labour's creative industries policies has been the poor understanding of the labour dynamics that characterise the work patterns of cultural and creative practitioners. Three key issues presented by Banks and O'Connor (2009) are the essential background to the analysis presented in this paper. Firstly, the utopianisation of work in the creative industries; secondly, the problematic tension between creative production and economic-commercial gains in creative work; finally, the lack of a consistent policy framework addressing the difference across UK regional policies and creative economy profiles, particularly in relation to the dominance of London.

Within this conflicting policy framework, we argue that the hype surrounding creative industries developed by New Labour policies and publications, combined with almost a decade of economic stability, has also had an impact on the growth of interest and student numbers in university degrees ideally directed towards creative careers (Heartfield, 2005). This hype specifically relates to the overall economic potential of the creative industries, presented both in national (DCMS, 1999b) and regional documents - as summarised by Jayne (2005) - as the new solution for economic growth in UK. These claims have been largely criticised by academic research (Oakley, 2006; C. Taylor, 2006) but still in 2009 the then Prime Minister Gordon Brown in one of his speeches addressed the creative industries as a means to 'pull Britain out of recession $^{\mathrm{i}}$ 
It is important to consider how this emphasis on the sector might have also affected students' choices over the last decade. In fact the Higher Education Statistical Agency (HESA2009) highlights the steady growth of creative subject areas. Among the 'creative' subjects, Architecture, Building and Planning saw a growth in student numbers of 34.2\% between 2003/2004 and 2007/2008, Creative arts and design had a 14.2\% increase, while Mass Communication and documentation $7.3 \%$ (against an overall growth of only $4.8 \%$ across all subjects).

Nowadays much of this rhetoric has been dismantled by researchers specifically addressing the poor labour condition and unstable working patterns of various creative careers, such as in film and television (Blair, 2000; Dex et al., 2000), theatre (Haunschild, 2003) media (Baines, 1999; Baumann, 2002) fine artists (NESTA, 2008) and craft makers (McAuley \& Fillis, 2005). However, as Banks and Hesmondhalgh (2009) also point out, this body of research had little translation in the New Labour policy, even in more recent publications such as Staying Ahead (The Work Foundation, 2008). Only the very last policy intervention Creative Britain (DCMS \& BERR, 2008) started recognising the instability of creative careers and more links to the educational framework.

One key issue that seems to be unaddressed both by academics and policy makers is the diversity of careers and job patterns experienced by workers across the creative industries. There is a lack of comparative knowledge to enable us to better understand what kind of creative careers might provide economic rewards and what kind of creative sectors suffer more from unstable work structures and markets.

Ultimately part of the problem arising by the Golden Age of New Labour Cultural policy is that it has been a Golden Age just for few and the creative industries became a rhetoric construction of the New Labour policy which hid some critical issues and realities (such as the poor career perspective of fine arts graduates) behind the larger positive economic trends mainly led by few highly commercial activities within the creative industries. This argument has previously been presented in relation to the national economic statistics available from the DCMS (Comunian, 2009; Oakley, 2006; C. Taylor, 2006), but it has never been treated in relation to the single individuals working in the creative industries.

The paper aims to explore the experience of individuals entering the creative job market - bohemian graduates (Comunian et al., 2010) - within the policy framework of the creative industries established during the New Labour government. While there has been recent work on the overall experiences of creative graduates (Ball et al., 2010) there is very limited knowledge of the relationship between studying choices and the career opportunities and patterns. Highlighting the differences in careers patterns and economic rewards experienced by the graduates of the academic year 2004/2005, the paper aims to question whether the creative industries as policy framework have really benefited prospective creative workers or if it has, on the contrary, facilitated the blurring of economic and structural differences across the creative industries into a positive portrait experienced only by few. 
In discussing the career patterns of the different bohemian graduates, we will also briefly present a picture of how these graduates are geographically distributed in the UK (both to study and to work). This is also a contested topic in relation to the New Labour cultural policy, because, while the importance of attracting creative workers in more peripheral regions has been recognised a key factor for regional success (Jayne, 2005) and has been the key goal of many regional initiatives (Chapain \& Comunian, 2010), the reality is that creative graduates tend to concentrate in few regions to study and even more so to work (Comunian \& Faggian, 2011).

The paper is organised as follows. Section 2 introduces the theoretical and policy background for our study. Section 3 briefly describes the data and methodology used. Section 4 presents and comments on the results while Section 5 draws some reflections and conclusions and policy implications of our findings. 


\section{Research landscape and framework}

The paper explores issues related to a complex research and policy landscape, involving an overlap of different disciplines and policy frameworks. Four key areas of discussion are briefly presented here in relation to the New Labour policy and activities: the working patterns and conditions of creative workers; the relation between creative workers and broader economic development discourses; the influence of creative industry and cultural policy discourses on higher education in the UK and the contradictions emerging in the analysis of the creative industries and its geography. Before addressing these issues a brief overview of New Labour policy interventions and cultural policy cornerstones are presented.

When the New Labour government was elected in 1997, it aimed to create a clear cut between the existent cultural policy and its future development. The sudden change in name of the then Department of National Heritage (DNH) to the Department of Culture, Media and Sport (DCMS) was not a simple change in label. The focus and interest towards the media and creative industries is presented by the then Secretary of State Chris Smith in the manifesto of the future cultural agenda 'Creative Britain' (Smith, 1998) and for the following decade the agenda was set for the objectives of cultural policy: "[...] to ensure excellence; to protect innovation; to assist access for as many people as possible, both to create and participate; to help provide the seedbed for the creative economy; and to assist in the regeneration of areas of deprivation" (Smith, 1998 p.18-19). The distinctive framework of the New Labour culture policy is in the new central role given to culture in a series of broader contexts, in particular the economic and the social interventions. Centrality in the economic discourse was endorsed both through presenting the creative industries as new sector for job creation and export (DCMS, 1999b), as well as linking it to the broader innovation agenda (DCMS \& BERR, 2008), and as an engine of local economic growth in local regeneration (mainly culture-led regeneration). Centrality in social interventions was again promoted within local cultural regeneration but also more broadly through the promotion of access and participation (NACCCE, 1999). While this new centrality of arts and culture was a new powerful perspective, often backed by arts and creative organizations, it also overloaded the sector with socio-economic responsibility (and accountability) which were out of its remit and control, causing alienation and a further questioning of the real role (and value) of culture (Arts Council England, 2008; Holden, 2004; Jowell, 2004).

Firstly, the paper draws on the literature addressing the working patters and condition of creative workers (Banks, 2007; Menger, 1999) and research looking at the training and development of people that aspire to have a career in the creative and cultural industries (Aston, 1999; Ball, 2003; Ball, et al., 2010; NESTA, 2008; Oakley, 2009). Building on the research framework developed by Comunian et al. (2010) the paper discusses the career patterns of 'bohemian graduates', i.e., graduates with a degree in a 'bohemian' subject (creative arts, performing arts, 
design, mass communications, multi-media, software design and engineering, music recording and technology, architecture and landscape design), and can be considered at the intersection between creative class, creative industries and human capital (see Figure 1).

\section{INSERT FIG. 1 HERE}

Although these graduates represent a relatively low percentage of the overall graduate population each year (they account for about $13 \%$ of the entire graduate population), it is interesting to study their working conditions as they are often presented as a key element in national and local economic development. Moreover, as the role played by the creative industries (and employment in these industries) was strongly linked in New Labour policy to local development, the geography and location of these individuals becomes also critical (as well as the policy aiming at the attracting or retaining them).

Secondly, the paper considers the link between creative work (and more broadly creative industries, creative class and creative economy) and broader economic development discourses (Florida, 2002a, 2002b). In doing so, we acknowledge that different researchers and policy makers have used the term 'creative work' with very different meaning sometimes departing quite considerably from the original framework by Florida (Florida, 2002c, 2006) which, despite having been highly-criticised (Comunian, 2010; Peck, 2005) has featured prominently in local and regional development policies.

Thirdly, the paper recognises that the New Labour cultural policy has had clear implications and connections with education policy and higher education in particular. Buckingham and Jones (2010) analyse the arguments put forward by policy reports such as All Our Futures (NACCCE, 1999), and that form the basis for national programmes such a Creative Partnership ii, to show the push by the New Labour's cultural and creative policies in the realm of education. The increasing emphasis on 'creativity' - both as a sector of the economy and as an acquirable skill - has permeated also the Higher Education (HE) sector. It opened up new possibilities for arts and humanities research to reach into the economy, via practices such as knowledge transfer and intellectual property (Bullen et al., 2004; Crossick, 2006; Smith et al., 2008). The Lambert review of business-university collaboration (HM Treasury, 2003), stating the need to include creative industries in the framework of business-university interactions $s^{\text {iii }}$, shows a willingness by many national bodies to include arts and humanities in the new economic development agenda (ACE2006; DCMS, 2006). The HE sector has embraced the creative industries hype even more closely in the development of creative regions (Powell, 2007). Interventions such as the development of the University Centre in Folkestone (Noble \& Barry, 2008) seem to have married the New Labour creative and cultural regeneration agenda with the provision of higher education in local - particularly peripheral - areas of the UK (Robinson \& Adams, 2008). Other initiatives, such as the 'Millions $+^{\text {iv }}$ in 2008, led on providing evidence of the role of universities in educating the future creative workforce and strongly emphasised the importance of HE institutions in engaging in this 
new policy agenda. Anecdotal case studies and reports highlight that the universities are already supporting the sector and its development. It should be noted, however, that, as in much New Labour policy interventions, there is little or no reference to the career difficulties faced by graduates in creative disciplines (Million + , 2008). Even more problematic is the lack of recognition that creative industries employers seem to be more attracted by the creative talent of individuals than their qualifications (Haukka, 2010) and that creative disciplines are taught mainly in non-Russell group universities (the ones which Million + mainly represents) which might have an effect on the salaries offered (see Comunian et al., 2010). Recently, Universities UK explored similar issues about the contribution of higher education to the creative economy. The creative industries rhetoric is full flagged 'there can be no doubt that the UK's creative economy is a jewel in our crown - a national success story and an area in which the UK can rightly claim to be a global leader' (Universities UK, 2010: i) and the role played by HE (both in respect to teaching, research and enterprise activities) is promoted, presented and exemplified. The only reference to possible difficulties faced by students is the recognition that "there is undoubtedly a need to ensure that graduates are fully prepared for working in what can be a demanding and uncertain environment" (Universities UK: 48).

Finally, the paper engages with the wider context of how the creative industries have been defined, measured and assessed during the New Labour government. The debate on these issues is very extensive (Galloway \& Dunlop, 2006; Oakley, 2004; Taylor, 2006). However, for the scope of this paper, there are few key aspects to consider: the role of economic rewards in creative careers, the diversity of sectors included within the creative industries and the geography of creative industries. Firstly, it seems that by merging arts and cultural activities into the broader creative industries umbrella, the New Labour cultural policy has ignored the contradiction between cultural work and monetarisation/economic value as perceived by creative practitioners (Banks, 2006; Taylor \& Littleton, 2008). So, in analysing the career perspectives of bohemian graduates it is important to look at both salaries (normally low) and career satisfaction (although Abreu et al. 2010 show that even job satisfaction is lower for bohemian graduates than other graduates three years and half after graduation). This paper is concerned with both whether 'bohemian' graduates are successful in finding a creative occupation and what is their economic reward. While it is clear that 'bohemian' graduates might find other career opportunities and economic benefit in other careers, it is assumed here that, having spent three years in developing specific creative skills at higher education level, their first career choice would be to enter a creative occupation. Secondly, the paper argues that while most of the literature portraits the 'creative industries' as a 'cohesive' group of sectors with respect to economic and job dynamics, this is an unexplored issue and in fact some initial comparison on the economic performance of different creative sectors reveals interesting differences (Chapain \& Comunian, 2009). Hence the need to better explore what impact different sub-disciplinary courses and education choices might have on employability and career performance of bohemian graduates. Finally, while national and regional policies (DCMS, 1999a; Jayne, 2005; Oakley, 2006) have struggled for a whole decade to make a difference in the distribution of opportunities in the creative economy in UK, all evidence gathered seems to suggest that most of the creative industries and 
creative workers are concentrated in Greater London and the South East (Clifton, 2008; Knell \& Oakley, 2007; NESTA, 2009), with more peripheral regions struggling in attracting and retaining graduates.

\section{Data, sample and methodology}

Our empirical analysis is based on data collected by the Higher Education Statistical Agency (from now on referred to as HESA). In the UK the Higher Education Statistics Agency (HESA) collects annual student record data, for all students, containing information on personal characteristics (such as age, gender, ethnicity), course characteristics (including subject studied at the 4-digit JACS codev, mode of studying, i.e. full-time or part-time, institution attended, final grade achieved for finalists) and location of parental domicile (at unit postcode level). Within UK higher education the institution attended can be placed into several different groups: Russell group universities (compromising of 20 research intensive universities who receive the majority of research grant and contract income), other old universities, new universities (established as part of the abolition of the binary divide in 1992) and Higher Education/Further education colleges. The Russell group universities, followed by the other old universities are generally considered to be more prestigious.

On behalf of HESA all higher education institutions are required annually to collect data on the destinations of their graduates six months after graduation, via the 'Destination of Leavers from Higher Education Institutions' (also known as DHLE) survey with a target response rate of $80 \%$ for British domicile students. The DHLE provides information on graduate employment six months after graduation, ${ }^{\text {vi }}$ this includes not only the salary and location of their job, but also a brief description of their tasks and the SOC4 (standard occupational code) and SIC4 (Standard Industrial Classification) codes of their occupation, in particular we focus on their ability to enter creative occupations.

We utilise data for British domiciled students (for whom we have information on both region of employment and domicile), belonging to the $2004 / 2005$ graduate cohort. The sample consists of a total of 442,518 finalists, of which we have 313,800 valid DHLE returns (see table 1 ). The sample includes both undergraduate and postgraduate students.

Creative occupations in this paper are defined using the DCMS (Department for Culture, Media and Sport) definition of creative industries and creative occupations ${ }^{\text {vii }}$. The DCMS framework (2009) is used to identify occupations within the creative industries (through Standard Industrial Classification codes) and creative occupations outside the creative industries (using Standard Occupation Classification codes). 
Students are classified, according to the subject studied, at two different levels. Firstly, we distinguish between bohemian and non-bohemian graduates ${ }^{\text {viii }}$. Broadly speaking bohemian graduates include students in creative arts \& design subjects (all JACS codes starting with W), creative media graduates (all JACS codes starting with P) and other creative graduates: subjects mainly linked to technologies-based creative subjects and architecture (for the list of JACS codes used in the category of bohemian graduates please refer to table in Appendix). This first categorisation $^{\mathrm{ix}}$ is helpful to compare and analyse the trends and data of bohemian graduates within the broader performance and career patterns of all the graduates in other disciplines (see also Comunian et al., 2010).

Secondly, since it is also important to understand what different trends and patterns emerged between graduates who studied different creative disciplines, we differentiate bohemian graduates into subgroups. Appendix 1 highlights the JACS codes classified as bohemian and their further split into 9 creative sub-categories namely Advertising, Architecture, Crafts, Design, Film and Television, Fine Art, Music, Performing arts, Technology ${ }^{x}$.

As table 1 summarises, 56,996 students graduated in 2004/2005 in creative disciplines in the UK (corresponding to 12.88\% of the students graduating that year). The larger sub-disciplinary groups are in the field of Design (3.33\% of the graduates' population), Film and Television (2.12\%) and Fine Art (1.56\%). Performing Arts, Music and Writing and Publishing students represent each just over $1 \%$ of the students' population, while students in creative technologies and architecture are just below $1 \%$ of the student population. The smallest group is represented by students in Crafts with only $0.08 \%$ of the overall student population. This first analysis of our sample already highlights the difficulty in defining an homogenous 'bohemian graduate' group as some subjects are more predominant than others which can be considered more of a 'niche'. An important consideration is whether the UK Higher Education institutions (HEls) are producing too many students in certain creative sub-groups, weakening their job market opportunities (Abbing, 2002; Towse, 2001).

\section{INSERT TABLE 1 HERE}

Alongside this national overview of the subjects studied by creative graduates, it is also important to consider where these students undertake their degrees. Table 2 shows the regional distribution of students undertaking creative degrees in the UK. As the table highlights, 35.54\% of the creative graduates concentrate in the Greater London and South-East area. As Comunian and Faggian (2011) suggest, this is strongly related to the concentration of highly specialised HEls in the capital region but also to the presence of HEls of large capacity (such as the University of Arts which cater for $6.8 \%$ of the overall bohemian graduate population). 
Another interesting dynamic emerging from table 2 is the further concentration of graduates from postgraduate courses in the Greater London area, while lower postgraduate numbers are presents in the surrounding regions South East, South West and East Midlands.

\section{INSERT TABLE 2 HERE}

The geography of HE provision is very important as it has a strong connection to the opportunity of regions to retain students and also embed them in local knowledge and business networks, which can have an impact in their future career direction.

Starting from this broad sample and geographical framework, the paper employs a three-step methodology which engages with three main research questions:

1. Firstly, we use some descriptive statistics to highlight where finalists concentrate to study creative disciplines and what degree of specialisation can be identified between geography and Bohemian students in general and across different sub-disciplines;

2. Secondly, using our DHLE sample, we produce some descriptive statistics to highlight similarities and differences between the sub-groups of the Bohemian graduate category in terms of career performance;

3. Finally, we use an OLS model (corrected for heteroscedasticity) to identify the main salary determinants and make sense of the salary discrepancies across the bohemian sub-disciplines. In line with traditional labour economics models, our model has the logarithm of nominal salaries as the dependent variable and a series of individual and regional characteristics as explanatory variables.

\section{Results}

\subsection{Bohemian graduates: distribution across regions and Higher Education Institutions}

As seen from the sample, the Greater London area represents a hub for bohemian students. It is interesting, however, to study whether this is true across all the creative sub-disciplines or whether there is a certain degree of regional specialisation in the HE system.

As highlighted in Table 3, although the largest number of creative students is predominantly concentrated in Greater London and the South East, some regional differences emerge. Advertising courses are more concentrated in the Yorkshire \& the Humber (22.01\%) and East 
Midlands (20.81\%) as well as in Scotland. Architecture is concentrated in the Greater London area (22.26\%), but Scotland (14.77\%) and East Midlands follow. Crafts courses are almost non-existent in the Greater London area (1.50\%) but concentrate heavily in the South West (23.65\%) and East Midlands (18.86\%). Design shows a strong dominance of Greater London (19.69\%) and the East Midlands (13.82\%) followed by the South East. Film and Television, and Fine Art show very similar patterns with a strong concentration - over $50 \%$ of students - in the South (Greater London, South East and South West). Music and Performing Arts have similar patterns with the leading region being Greater London and the South East and North West to follow. Yorkshire and the Humber, with (18.65\%), follows closely Greater London (22.58\%) in terms of creative technology students, while Writing and Publishing students are concentrated (after Greater London) in the North West and East Midlands.

\section{INSERT TABLE 3 HERE}

It is also interesting to notice that certain regions show high level of specialisation as they do not host many creative students but they host them in very specific fields. For example, in some cases the percentage of graduates in a specific field is double the percentage of overall creative graduates in the region: crafts courses are a flagship of the South West, advertising and creative technology of Yorkshire and the Humber, crafts and advertising of East Midlands, advertising and architecture of Scotland, crafts of the West Midlands and writing and publishing of Wales and Northern Ireland.

While this geography shows the dominance of the Greater London (and more broadly of the South) in many subjects, it is not entirely clear which (if any) of these subjects provide the students with a more secure and economically rewarding career and how geography interlinks with the career patterns of students in different creative sub-disciplines.

Following on work by Comunian et al. (2010) who show that the characteristics of the HEls attended might have bearings on graduate entry salaries and career patterns, we look at the distribution of the different creative subjects across the HEls 'type', i.e., Russell group universities, Other 'Old' universities, New universities and Colleges. As it clearly emerges from table 4, creative subjects are predominantly taught in Colleges and New universities, with Colleges being the leading providers in Design, Film and television, fine arts, music, performing arts and writing and publishing, and New universities leading in the provision of crafts and creative technology courses. The only two creative subdisciplines with a considerable presence in Russell group universities are music and architecture.

INSERT TABLE 4 HERE

\subsection{Bohemia graduates and their work patterns}


The data presented so far helped us better understanding the key patterns in the provision of creative courses across different regions and HEls in the UK, this section will focus, instead, on the employment opportunities offered to creative graduates across different sub-disciplines. Before looking at the differences between sub-disciplines, however, it is useful to have a look at some more general patterns. Table 5 highlights the overall different trends between non-bohemian and bohemian graduates. Consistent with previous analysis (Abreu et al., 2010; Comunian et al., 2010) - which was making use of different cohorts of students and graduates - bohemian graduates are less likely (53.77\%) to have a full-time paid work than non-bohemian graduates $(57.39 \%)$ and more likely to have a part-time job (10.53\% against $7.19 \%)$. They also experience more voluntary and unpaid work and are less likely to be undertaking further studies. More worryingly, they are almost twice more likely to be unemployed than other graduates.

\section{INSERT TABLE 5 HERE}

However, a breaking down of these figures by creative sub-disciplines (Table 6) shows that not all creative graduates are more likely to be unemployed than other graduates. Students in advertising, writing and publishing and architecture are performing even better than the general non-creative graduate group as their percentage of full-time employment is between $65.88 \%$ and $59.19 \%$ against $57.39 \%$ of noncreative graduates and $53.77 \%$ of the creative graduates overall. For graduates in advertising and architecture part-time work is also very low (lower than the non-creative students group) while it is very high for graduates in craft and fine arts.

Voluntary and unpaid work is higher for advertising and fine arts, but is similar across the other sub-groups. Combining work with studying is common for architecture graduates, due to the specific career structure of the field. Enrolling in further education is very high only in the crafts and music disciplines (respectively $18.47 \%$ and $22.01 \%$ ).

Unemployment is very unevenly spread across the sub-groups. While it is high in film and television, creative technologies and design and fine arts, it is very low (lower or comparable to the general non-bohemian graduates population) for architecture, craft and music graduates.

\section{INSERT TABLE 6 HERE}

To get a better understanding of the career patterns of creative graduates we also consider their likelihood of entering a creative occupation. Table 7 shows that the differences across sectors are quite important. Overall, only $37.60 \%$ of creative graduates enter creative occupations (it is argued by Comunian et al. 2010 and Abreu et al. 2010 that this has implications for their job satisfaction and salary). However, architecture students find a creative occupation in $81.03 \%$ of the cases; the other sub-groups that perform better than the average of the creative group are design (40.19\%) and advertising (42.81\%). The sub-disciplines with the worst performance are fine arts (22.60\%), craft (24.71\%), and music 
(29\%). While the professional structure of architecture facilitates the employment of graduates in the creative field, the unstructured nature of career in fine arts, craft and music seem to emerge as a real obstacle for entering creative occupations. It is also evident from table 7 that London dominates the offer of creative occupations across all the sub-disciplines. So while the regional distribution of students attending creative courses showed a diversification of subjects' concentration across different regions, these differences seem to disappear in reference to job opportunities, as London drives and concentrates most of the creative occupations.

\section{INSERT TABLE 7 HERE}

The different likelihood of entering a creative occupation is also linked to the salary levels of the different sub-disciplines (see Table 8). Architecture and creative technology graduates have the highest entry salaries (a mean respectively of 18,000 and 17,000 pounds a year, against a mean of $£ 15,000$ a year for the overall bohemian category). On the opposite end of the spectrum, craft, performing arts and film and television students earn the lowest salaries (respectively a mean salary of $£ 11,000$ and $£ 14,000$ pounds a year).

There are interesting differences emerging across sub-sectors in reference to whether entering a creative or non-creative career has economic advantages or disadvantages. For most disciplines entering a creative occupation has economic benefits (in the regions of an increased income of $£ 1,000$ to $£ 2,000$ a year). However, for other sub-disciplines there are no differences, or, even worse, a creative occupation is associated with a lower salary. This is the case, for instance, for fine art and music graduates who lose respectively $£ 4,000$ and $£ 1,000$ when entering a creative occupation as opposed to a non-creative. This seems to suggest that the 'generic' human capital acquired by these graduates via their tertiary education - also labelled by some 'transferrable skills' - is more valuable to them than their 'specific' human capital, i.e. the skills specific to their sector. It also points to some specific difficulties experienced by these sectors in providing graduates with the appropriate economic rewards.

\section{INSERT TABLE 8 HERE}

\subsection{The geography of bohemian graduates' creative occupations and salaries}

In this section we focus on the geography of creative occupations starting from a very general picture to then enter into more specific details. Table 7 showed that creative occupations represent around $11.11 \%$ of occupations in the 2004/2005 graduates' sample. Table 9 shows the geographical distribution of these occupations. As to be expected, the proportion of 'creative' jobs in London is much higher than the overall 
proportion of 'all' graduate jobs and also the share of the UK labour force. The opposite holds for all the other regions with the only exception of the South East which has a slightly higher proportion of creative occupations than graduate occupations (but a higher share of the labour force). As we can see from the share of total UK workforce, London - differently from all other regions - is a bigger driver for the creative occupations than non-creative occupations.

\section{INSERT TABLE 9 HERE}

Other interesting differences emerge if we look at the regional spread of creative occupations across the different sub-disciplines (Table 10). For example $45.94 \%$ of film and television, $41.10 \%$ of music and $44.00 \%$ of performing arts graduates with creative jobs are in London, whilst only $10.53 \%$ of craft graduates with creative jobs are in London and more (18.42\%) are in the South East and West Midlands (15.79\%). More than expected advertising and architecture students with creative jobs are in Scotland.

Another interesting consideration can be derived by comparing the distribution of creative graduates in reference to their region of study (Table 3) and the regional distribution of creative occupations (Table 9). While $22.13 \%$ of the bohemian graduates studied in Greater London, $34.21 \%$ of creative occupations are located there. Also in the East of England and Northern Ireland there is larger share of creative occupations than bohemian students. In all the other regions, the share of bohemian students is higher than the creative occupations offered, with the only exception of Scotland (where the share of graduates and jobs is almost the same).

\section{INSERT TABLE 10 HERE}

Geography not only makes a difference in the likelihood of accessing creative careers, it also has an impact on the entry salaries of graduates. Table 11 presents the results of our model looking specifically at the determinants of the salaries of creative graduates ${ }^{\mathrm{xi}}$. By looking at the different regions, we notice that the coefficient of London is, as expected, positive and significant, while the coefficients of Northern Ireland and Yorkshire are negative and significant (lower entry salaries for creative graduates).

Other results are worth mentioning too. Looking at the sub-disciplines, for instance, Technology graduates have the highest salaries followed by Advertising and Writing and Publishing. All the others are not significantly different, except Fine Art which is lower (even though only 
significant at 10\%). As far as individual characteristics are concerned more mature and male graduates earn on average a higher salary, which is consistent with most labour economics and creative literature. Finally, in line with the traditional human capital theory (Becker, 1964), graduates with lower final grades and coming from 'perceived' less prestigious HEls (colleges and further education institutions) benefit from lower salaries when entering the labour market.

\section{INSERT TABLE 11 HERE}

\section{Discussion and Conclusions}

The central argument of the paper is that, while the New Labour cultural policy has widely promoted the creative industries and creative careers in the UK highlighting how important they are for growth, graduates in these fields are still facing rather uncertain and unfavourable labour market conditions. While there are some 'golden opportunities' for some creative graduates, the majority of them has poor career perspectives at least in the short to medium term (Abreu et al., 2011). Analysing the career patterns experienced by bohemian students, who graduated in 2005 - at the very peak of New Labour cultural policy and just before the upcoming recession - we found that there really never was a 'golden age' for jobs and career opportunities in the creative industries.

Moreover, the New Labour Cultural policy has promoted the creative industries as a whole but never paid much attention to the differences among creative sub-disciplines. Our data show that only few of these creative sectors are able to deliver sustainable career paths and a healthy job market for graduates. Among the creative sectors advertising, architecture and writing and publishing are the ones offering more job stability and higher economic rewards, while craft, performing arts, film and television and fine arts graduates are facing uncertainty and poorer work conditions.

Our results also show that in the UK, despite the geographical spread of HEls providing creative courses, Greater London dominates the creative occupations market. Most creative occupations find their natural setting in large conurbations rather than more peripheral locations.

The role of research is to point out these barriers faced by bohemian graduates in entering creative occupation and to function as a reality check for a cultural policy blinded by supporting arguments in favour of culture (Belfiore, 2009) and raising unrealistic expectations for people entering the creative and cultural field.

However, as Belfiore (2009) suggests, it is not just cultural policy that needs a reality check, but academia as well. While research has pointed out the short-coming of creative education - not in reference to its intrinsic value but to employability and career opportunities - many HEls 
have expended their offer in these fields without questioning the real opportunities available to bohemian graduates (Heartfield, 2005). There is very little acknowledgment in policy documents developed by the HE sector of the difficulties faced by bohemian graduates in entering the creative job market.

Reflecting on the analysis of Buckingham and Jones (2010) on the relation between cultural policy and education under the New Labour government, it seems that much of the enthusiasm towards the value of cultural and creativity - both intrinsically and in the economy - has quickly translated into HE provision of creative courses. However, as the authors point out 'there is a danger that 'creativity' and 'culture' will come to be seen as magic ingredients that will automatically transform education" (p. 13). New Labour cultural policy has translated in higher education provision in a belief that creativity and creative courses would automatically translate in employability and high economic competiveness, under the banner of the greater economic and social contribution of creative activities to our national economy. However, our analysis suggests that the creative skills of graduates in these disciplines are not fully valued and appreciated in the job market (both in creative and non creative occupations) and that the hype surrounding the creative industries has created an 'economic bubble' that has further expanded the provision of those skills without real corresponding opportunities. Lower economic rewards are then linked back to issues of oversupply already identified by Towse (2001) and Abbings (2002).

The literature acknowledges that creative workers follow different careers rewards rather than simply higher economic returns (Throsby \& Hollister, 2003), and this could be true also for students undertaking creative degrees. In this present study - as HESA data are used - it has not been possible to look at the different career opportunities offered to creative workers with a creative degree and creative workers without a degree. However, it is further recognised in the broader literature that a degree does not represent a secure entry point for the creative job market (Haukka, 2010) and this needs to be taken into consideration to explore disparities in the creative job market ${ }^{\text {xii }}$.

This also reflects in the geography of opportunities. While the New Labour cultural policy has tried to address the disparity of infrastructure and opportunities available across the UK regions, we find, in line with other studies (Clifton, 2008; Comunian \& Faggian, 2011), that career opportunities in the creative occupations are strongly concentrated in London and the South East.

While the expansion of the higher education sector, and of new HEls specifically catering for creative subjects, was part of a long-term strategy aiming at attracting and retaining 'creativity' also more peripheral areas, it seems that bohemian graduates still highly concentrate in few key urban areas and Greater London in particular, where job opportunities are located (Comunian \& Faggian, 2011). 
While more longitudinal research is needed to draw a more detailed picture of the barriers faced by creative graduates, not only in the year of graduation, but also as they establish their portfolio and develop in the work market, it is important to consider what policy implications and recommendations can emerge by the current findings (and how they could be questioned or tested in further research). These recommendations relate both to national policy frameworks and HEls practice in the creative economy.

With regards to the first, it seems clear that the term creative industries (and creative economy) have been created in a decade of strong investment in both the public and private cultural and creative sector. The current recession seems to highlight the need to adopt a more 'finegrain' approach towards the creative sectors, which presents not only successful cases, but more honestly portraits what difficulties and barriers are embedded in each sub-sector and how they might be overcome.

As for the latter, it seems that creative disciplines within HEls are still finding it hard to engage with the creative job market in an effort to improve employability. Although there are examples of universities opening up to the creative job market and embracing business education alongside creative education, the New Labour policy has not particularly facilitated the creation of a "virtuous cycle" (Matheson, 2006) between higher education and the creative industries. Hard selling the creative industries as a leading sector has created expectations too hard to deliver and a more realistic take into the development of the future creative workforce is needed.

\section{Acknowledgements}

We acknowledge the support of the "Impact of Higher Education Institutions on Regional Economies Initiative" (ESRC grant number RES-17125-0032 co-funded by HEFCE, Scottish Funding Council, HEFCW and DELNI). The authors also wish to thank HEFCE and HESA for providing access to the data used in this study. Nevertheless, all views expressed are solely the responsibility of the authors. 


\section{References}

Abbing, H. (2002). Why are artists poor?: the exceptional economy of the arts Amsterdam Amsterdam University Press.

Abreu, M., Faggian, A., Comunian, R., \& McCann, P. (2010). "Life is short, art is long": From Bohemian graduates to the creative class. Paper presented at the Western Regional Science Association, 49th Annual Meeting

Arts Council England. (2008). McMaster Review: Supporting excellence in the arts - from measurement to judgement. London: ACE.

Arts Council England (ACE). (2006). Arts, Enterprise and Excellence: Strategy for Higher Education. London: Arts Council England.

Aston, J. (1999). Ambitions and Destinations: the Careers and Retrospective Views of Art and Design Graduates and Postgraduates. International Journal of Arts and Design Education, 18(2), 231-240.

Baines, S. (1999). Servicing the media: freelancing, teleworking and 'enterprising careers'. New Technology, Work and Employment, 14(1), 1831.

Ball, L. (2003). Future Directions for Employability Research in the Creative Industries. http://www.adm.heacademy.ac.uk/resources/resources-by-topic/employability/future-directions-for-employability-research-in-thecreative-industries (accessed 12th May 2009)

Ball, L., Pollard, E., \& Stanley, N. (2010). Creative graduates, creative futures. . London: Creative Graduates Creative Futures Higher Education Partnership and the Institute for Employment Studies.

Banks, M. (2006). Moral Economy and Cultural Work. Sociology, 40(3), 455-472.

Banks, M. (2007). The Politics of Cultural Work: Palgrave MacMillan.

Banks, M., \& Hesmondhalgh, D. (2009). Looking for work in the creative industries policy. International Journal of Cultural Policy, 15(4), 415 430.

Banks, M., \& O'Connor, J. (2009). After the creative industries. International Journal of Cultural Policy, 15(4), 365-373.

Baumann, A. (2002). Informal labour market governance: the case of the British and German media production industries. Work, Employment and Society, 16(1), 27-46.

Belfiore, E. (2009). On bullshit in cultural policy practice and research: notes from the British case. International Journal of Cultural Policy, 15(3), 343-359.

Blair, H. (2000). You are only as good as your last job: the labour process and labour market in the British film industry. Work, employment and society, 15(1), 149-169.

Buckingham, D., \& Jones, K. (2010). New Labour's cultural turn: some tension in contemporary educational and cultural policy. Journal of Education Policy, 16(1), 1-14.

Bullen, E., Robb, S., \& Kenway, J. (2004). 'Creative Destruction': knowledge economy policy and the future of the arts and humanities in the academy. Journal of Education Policy, 19(1), 3 - 22.

Chapain, C. A., \& Comunian, R. (2009). Creative Cities in England: Researching Realities and Images. Built Environment, 35(2), $212-229$. 
Chapain, C. A., \& Comunian, R. (2010). Enabling and Inhibiting the Creative Economy: The Role of the Local and Regional Dimensions in England. Regional Studies, 43(6), 717-734.

Clifton, N. (2008). The "creative class" in the UK: an initial analysis. Geografiska Annaler: Series B, Human Geography, 90(1), 63-82.

Comunian, R. (2009). Questioning creative work as driver of economic development: the case of Newcastle-Gateshead. Creative Industries Journal, 2(57-71).

Comunian, R. (2010). Rethinking the creative city: the role of complexity, networks and interactions in the urban creative economy. Urban Studies forthcoming.

Comunian, R., \& Faggian, A. (2011). Higher Education and the Creative City. In C. Mellander, A. Andersson \& D. Andersson (Eds.), Handbook on Cities and Creativity London/ New York: Edward Elgar.

Comunian, R., Faggian, A., \& Li, Q. C. (2010). Unrewarded careers in the creative class: The strange case of Bohemian graduates. Papers in Regional Science, 89 (2), 389 - 410

Crossick, G. (2006). Knowledge transfer without widgets: The challenge of the creative economy. Paper presented at the Lecture, Royal Society of Arts.

DCMS. (1998). Creative Industries Mapping Document London: Department for Culture, Media and Sport.

DCMS. (1999a). Creative Industries - The regional dimension. London: Department for Culture, Media and Sport.

DCMS. (1999b). Creative Industries Exports - Our hidden potential. London: Department for Culture, Media and Sport.

DCMS. (2001). Creative Industries Mapping Document London: Department for Culture, Media and Sport.

DCMS. (2003). Regional Cultural Data Framework, a report by Positive Solutions, Business Strategies, Burns Owens Partnership and Andy C. Pratt. London: DCMS (Department for Media, Culture and Sport).

DCMS. (2006). Making the case for Public Investment: Developing Entrepreneuriship for the Creative Industries - The role of Higher Education. London: DCMS

DCMS, \& BERR. (2008). Creative Britain - New Talents for the Economy. London: DCMS.

Dex, S., Willis, J., Paterson, R., \& Sheppard, E. (2000). Freelance Workers and Contract Uncertainty: The effects of Contractual Changes in the Television Industries. Work, Employment and Society, 14(2), 283-305.

Elias, P., Mcknight, A., Purcell, K., \& Pitcher, J. (Eds.). (1999). Moving on: graduate careers three years after graduation. Manchester: CSU/DfEE. Florida, R. (2002a). Bohemia and economic geography. Journal of Economic Geography, 2, 55-71.

Florida, R. (2002b). The Economic Geography of Talent. Annals of the Association of American Geographers, $92(4), 743-755$.

Florida, R. (2002c). The Rise of the Creative Class. New York: Basic Books.

Florida, R. (2006). The Flight of the Creative Class. New York: HarperBusiness.

Galloway, S., \& Dunlop, S. (2006). Deconstructing the Concept of 'Creative Industries'. In C. Eisenberg, R. Gerlach \& C. Handke (Eds.), Cultural Industries: The British Experience in International Perspective (Vol. Available: http://edoc.hu-berlin.de). Online: Humboldt University Berlin. 
Haukka, S. (2010). From education to work in Australia's creative digital industries: comparing the opinions and practices of employers and aspiring creatives. Brisbane: Queensland Institute of Technology.

Haunschild, A. (2003). Managing Employment Relationships in Flexible Labour Markets: The Case of German Repertory Theatres. Human Relations 56(8), 899-929.

Heartfield, J. (2005). The Creativity Gap. London: Blueprint, ETP Ltd.

Higher Education Statistical Agency (HESA). (2009). Press release 141- Science and Medicine studies see five year growth. Cheltenham: HESA.

HM Treasury. (2003). The Lambert review of business-university collaboration. London: The Stationary Office.

Holden, J. (2004). Capturing Cultural Value: How culture has become a tool of government policy. London: DEMOS.

Jayne, M. (2005). Creative industries: the regional dimension? Environment \& Planning C: Government \& Policy, 23,537 - 556.

Jowell, T. (2004). Government and the Value of Culture. London: DCMS.

Knell, J., \& Oakley, K. (2007). London's Creative Economy: An Accidental Success? London: The Work Foundation.

Matheson, B. (2006). A culture of creativity. design education and the creative industries. Journal of Management Development, 25(1), 55-64.

McAuley, A., \& Fillis, I. (2005). Careers and Lifestyles of Craft Makers in the 21st Century. Cultural Trends, 14(2), 139 - 156.

McKnight, A. (1999). Graduate employability and performance indicators, first destinations and beyond. In P. Elias, A. Mcknight, K. Purcell \& J. Pitcher (Eds.), Moving On: Graduate careers three years after graduation. Manchester: CSU/DfEE.

Menger, P. M. (1999). Artistic Labor Markets and Careers. Annual Review of Sociology, 25, 541-574.

Million +. (2008). Creative Futures: Building the Creative Economy through Universities. London: Million +

National Advisory Committee on Creative and Cultural Education (NACCCE). (1999). All Our Futures: Creativity, Culture and Education. London: DFEE and DCMS.

NESTA. (2008). The art of innovation: how fine arts graduates contribute to innovation. London: NESTA.

NESTA. (2009). The geography of creativity. London: NESTA.

Noble, M., \& Barry, T. (2008). Supporting Regional Regeneration and Workforce Development: Establishing a new University Centre in Folkestone Paper presented at the UVAC Annual Conference Higher Education - Skills in the Workplace: Delivering employer-led higher level work-based learning

Oakley, K. (2004). Not So Cool Britannia: The Role of the Creative Industries in Economic Development. International Journal of Cultural Studies, 7(1), 67-77.

Oakley, K. (2006). Include Us Out-Economic Development and Social Policy in the Creative Industries. Cultural Trends, $15(4), 255$ - 273.

Oakley, K. (2009). From Bohemian to Britart - art students over 50 years. Cultural Trends, 18(4), 281 - 294.

Peck, J. (2005). Struggling with the Creative Class. International Journal of Urban and Regional Research, 29, 740-770.

Powell, J. (2007). Creative universities and their creative city-regions. Industry and Higher Education, 21(6), 323-335.

Pratt, A. C. (1997). The cultural industries production system: a case study of employment change in Britain, 1984-91. Environment and Planning A, 29(11), 1953-1974. 
Robinson, C., \& Adams, N. (2008). Unlocking the potential: the role of Universities in pursuing regeneration and promoting sustainable communities. Local Economy, 23(4), 277-289.

Smith, C. (1998). Creative Britain. London: Faber \& Faber.

Smith, D., Taylor, C., \& Comunian, R. (2008). Universities in the cultural economy: bridging innovation in arts and humanities and the creative industries Paper presented at the ICCPR 2008 - International Conference on Cultural Policy Research.

Taylor, C. (2006). Beyond Advocacy: Developing an Evidence Base for Regional Creative Industry Strategies. Cultural Trends, 15(1), 3 -18.

Taylor, S., \& Littleton, K. (2008). Art work or money: Conflicts in the construction of a creative identity. Sociological Review, 56(2), 275-292.

The Work Foundation. (2008). Staying ahead: the economic performance of the UK's creative industries. London: The Work Foundation.

Throsby, D., \& Hollister, H. (2003). Don't give up your day job: an economic study of professional artists in Australia. Sydney: Australia Council.

Towse, R. (2001). Partly for the Money: Rewards and Incentives to Artists. KYKLOS, 54(2/3), 473-490.

Universities UK. (2010). Creating Prosperity: the role of higher education in driving the UK's creative economy. London Universities UK. 
Figure 1: The 'Bohemian' graduate research framework

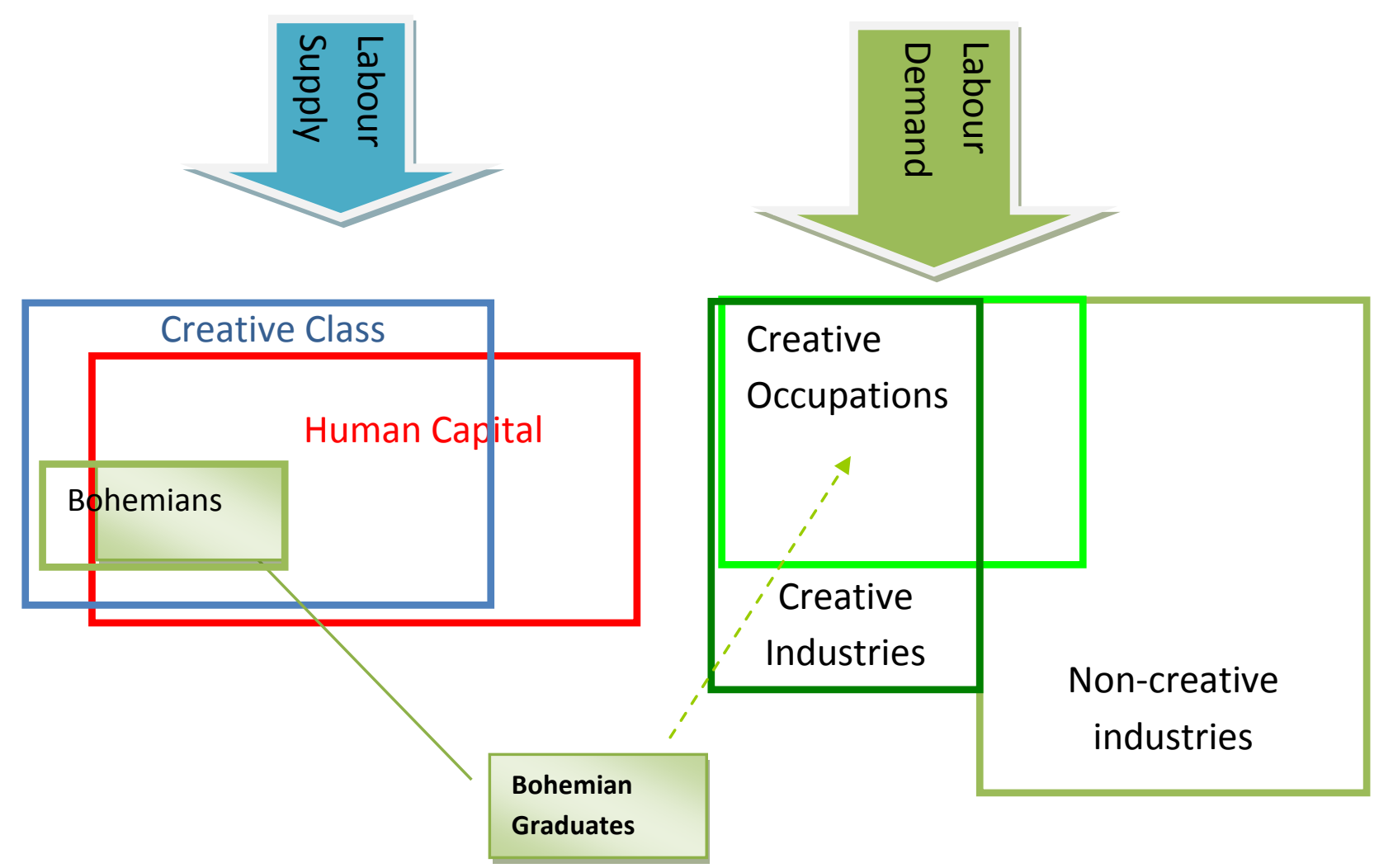


Table 1: Our samples: finalists and DLHE returns in 2004 / 2005

\begin{tabular}{|r|c|c|c|c|}
\hline \multirow{2}{*}{ Subject groups } & \multicolumn{2}{|c|}{ Finalists } & \multicolumn{2}{c|}{ DLHE Returns } \\
\hline Non - bohemians & 385,522 & 87.12 & 271,917 & 86.65 \\
\hline Bohemians & 56,996 & 12.88 & 41,883 & 13.35 \\
\hline Advertising & 1,086 & 0.25 & 762 & 0.24 \\
\hline Architecture & 3,805 & 0.86 & 2,492 & 0.79 \\
\hline Crafts & 334 & 0.08 & 249 & 0.08 \\
\hline Design & 14,717 & 3.33 & 11,084 & 3.53 \\
\hline Film and Television & 9,361 & 2.12 & 6,938 & 2.21 \\
\hline Fine Art & 6,891 & 1.56 & 5,191 & 1.65 \\
\hline Music & 5,299 & 1.2 & 4,052 & 1.29 \\
\hline Technology & 4,380 & 0.99 & 3,070 & 1.47 \\
\hline Writing and Publishing & 4,977 & 1.12 & 3,423 & 1.09 \\
\hline & 442,518 & 100 & 313,800 & 100 \\
\hline
\end{tabular}

Notes: Finalists refer to all those graduating in 2004/2005 whilst the DLHE return sample refers to those who completed a DLHE return 
Table 2: Percentage of Bohemian graduates distribution across UK regions (finalists sample)

\begin{tabular}{|l|c|c|c|}
\hline & \multicolumn{3}{|c|}{ \% of Bohemian graduates on UK total } \\
\hline Region & All & UG & PG \\
\hline Greater London & 22.13 & 19.93 & 31.7 \\
\hline South East & 13.41 & 14.26 & 9.74 \\
\hline North West & 9.87 & 10.05 & 9.1 \\
\hline South West & 9.2 & 9.73 & 6.89 \\
\hline Yorkshire \& the Humber & 9.16 & 9.00 & 9.16 \\
\hline East Midlands & 9.03 & 10.09 & 5.12 \\
\hline Scotland & 6.82 & 6.58 & 7.87 \\
\hline West Midlands & 6.45 & 6.44 & 6.5 \\
\hline Wales & 5.85 & 5.92 & 5.56 \\
\hline East of England & 3.39 & 3.42 & 3.03 \\
\hline North East & 3.35 & 3.19 & 4.28 \\
\hline \hline Northern Ireland & $\mathbf{1 . 3 4}$ & $\mathbf{1 . 4 1}$ & $\mathbf{1 . 0 5}$ \\
\hline
\end{tabular}


Table 3: Distribution of creative graduates by subjects across UK regions (darker cells highlight the top 3 regions for each subject area)

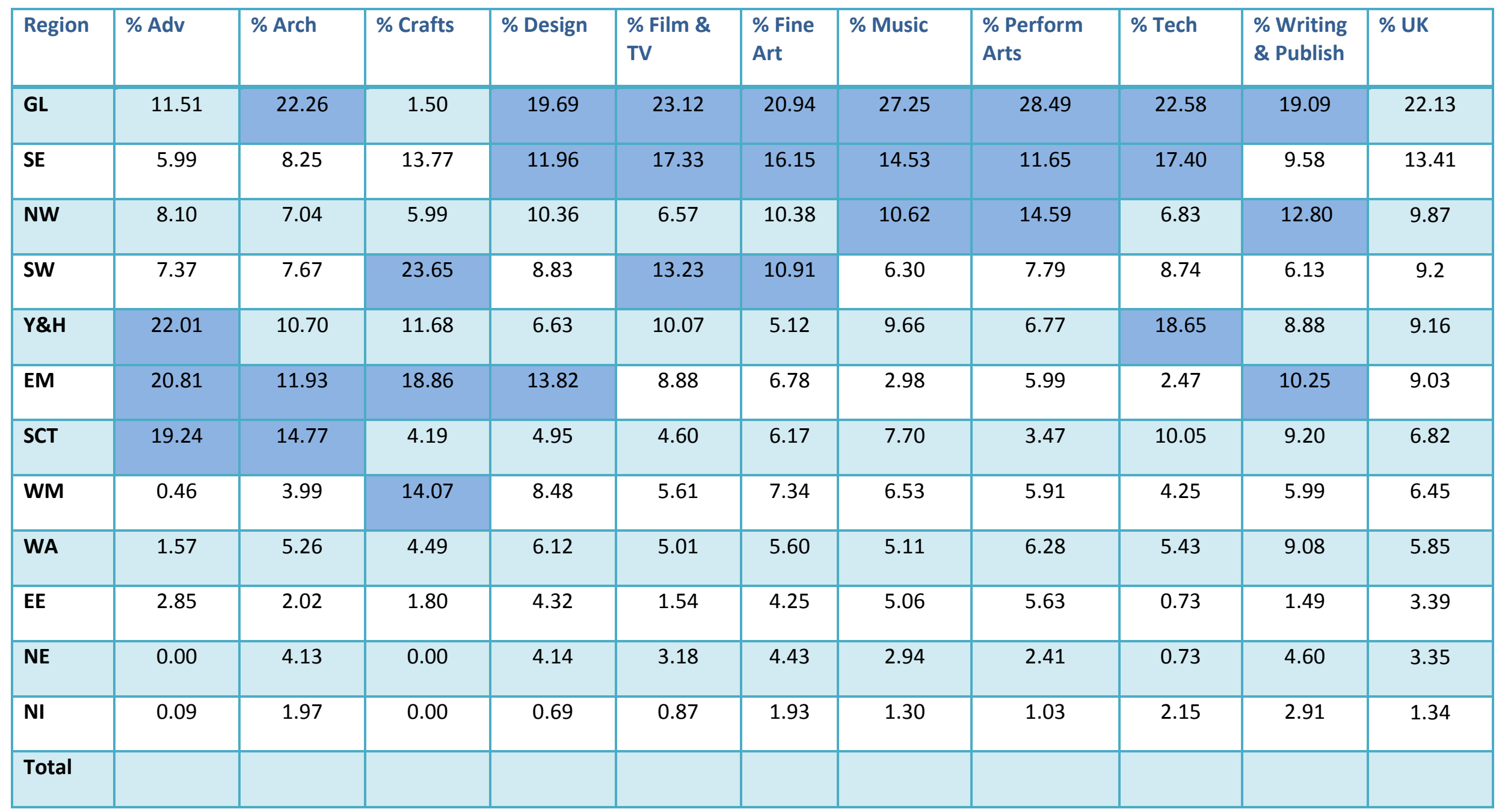


Table 4: Distribution of creative graduates by discipline and HEl type (darker cells highlight highest and second-highest percentages over the average distribution of subjects)

\begin{tabular}{|c|c|c|c|c|c|c|c|c|c|c|c|c|c|c|}
\hline \multirow[t]{2}{*}{ HEI Type } & \multirow{2}{*}{$\begin{array}{c}\mathbf{N} \\
\text { HEls }\end{array}$} & \multirow{2}{*}{$\begin{array}{c}\text { \% UK } \\
\text { student }\end{array}$} & \multicolumn{12}{|c|}{ Subjects (\%) } \\
\hline & & & $\begin{array}{c}\text { Non- } \\
\text { bohemian }\end{array}$ & Bohemian & Adv & Arch & Crafts & Design & $\begin{array}{c}\text { Film \& } \\
\text { TV }\end{array}$ & $\begin{array}{c}\text { Fine } \\
\text { Art }\end{array}$ & Music & $\begin{array}{c}\text { Performing } \\
\text { Arts }\end{array}$ & Tech & $\begin{array}{c}\text { Writing and } \\
\text { Publishing }\end{array}$ \\
\hline $\begin{array}{l}\text { Russell } \\
\text { group }\end{array}$ & 20 & 22.32 & 94.86 & 5.14 & 0.11 & 1.21 & 0.01 & 0.40 & 0.33 & 0.42 & 1.09 & 0.52 & 0.14 & 0.91 \\
\hline $\begin{array}{l}\text { Other } \\
\text { 'Old' }\end{array}$ & 44 & 25.92 & 93.04 & 6.96 & 0.06 & 0.28 & 0.02 & 1.08 & 1.13 & 0.82 & 0.92 & 1.00 & 0.65 & 0.99 \\
\hline New & 48 & 41.54 & 82.85 & 17.15 & 0.41 & 1.07 & 0.13 & 5.46 & 2.99 & 2.05 & 0.94 & 1.17 & 1.66 & 1.26 \\
\hline Colleges & 56 & 10.22 & 72.54 & 27.46 & 0.34 & 0.71 & 0.11 & 6.72 & 4.95 & 3.89 & 3.19 & 5.18 & 0.98 & 1.38 \\
\hline Total & 168 & 100 & 87.12 & 12.88 & 0.25 & 0.86 & 0.08 & 3.33 & 2.12 & 1.56 & 1.20 & 1.39 & 0.99 & 1.12 \\
\hline
\end{tabular}


Table 5: Employment profile of bohemian and non-bohemian graduates (dark cells highlight the highest percentage in the two groups bohemian / non-bohemians)

\begin{tabular}{|l|c|c|c|c|}
\hline Destination & Non-bohemians & Percentage & Bohemians graduates & Percentage \\
\hline Full-time paid work & 156,041 & 57.39 & 22,519 & 53.77 \\
\hline Part-time paid work & 19,545 & 7.19 & 4,409 & 10.53 \\
\hline Voluntary/Unpaid work & 1,825 & 0.67 & 404 & 0.96 \\
\hline Work and Study & 28,205 & 10.37 & 3,224 & 7.7 \\
\hline Further Study only & 34,018 & 12.51 & 4,682 & 11.18 \\
\hline Assumed to be unemployed & 12,836 & 4.72 & 3,195 & 7.63 \\
\hline $\begin{array}{l}\text { Not available for } \\
\text { employment }\end{array}$ & 11,036 & 4.06 & 1,705 & 4.07 \\
\hline Other & 2,648 & 0.97 & 675 & 1.61 \\
\hline Explicit refusal & 5,763 & 2.12 & 1,070 & 2.55 \\
\hline & & & & \\
\hline Total & 271,917 & 100 & 41,883 & 100 \\
\hline
\end{tabular}


Table 6: Emerging work profiles across creative disciplines (darker cells highlight highest 3 sub-disciplinary groups for each work profile)

\begin{tabular}{|c|c|c|c|c|c|c|c|c|c|c|}
\hline Destination & Adv & Arch & Crafts & Design & Film \& TV & Fine Art & Music & $\begin{array}{l}\text { Perform } \\
\text { Arts }\end{array}$ & Techn & $\begin{array}{l}\text { Writing \& } \\
\text { Publishing }\end{array}$ \\
\hline \multirow{2}{*}{$\begin{array}{l}\text { Part-time paid } \\
\text { work }\end{array}$} & 49 & 82 & 43 & 1,174 & 783 & 711 & 468 & 549 & 268 & 282 \\
\hline & $6.43 \%$ & $3.29 \%$ & $17.27 \%$ & $10.59 \%$ & $11.29 \%$ & $13.70 \%$ & $11.55 \%$ & $11.88 \%$ & $8.73 \%$ & $8.24 \%$ \\
\hline $\begin{array}{l}\text { Voluntary/Unpa } \\
\text { id work }\end{array}$ & $1.18 \%$ & $0.44 \%$ & $0.40 \%$ & $1.08 \%$ & $1.04 \%$ & $1.35 \%$ & $0.72 \%$ & $1.04 \%$ & $0.65 \%$ & $0.70 \%$ \\
\hline \multirow[t]{2}{*}{ Work and Study } & 31 & 415 & 26 & 767 & 408 & 464 & 367 & 327 & 204 & 215 \\
\hline & $4.07 \%$ & $16.65 \%$ & $10.44 \%$ & $6.92 \%$ & $5.88 \%$ & $8.94 \%$ & $9.06 \%$ & $7.07 \%$ & $6.64 \%$ & $6.28 \%$ \\
\hline \multirow{2}{*}{$\begin{array}{l}\text { Further Study } \\
\text { only }\end{array}$} & 46 & 287 & 46 & 975 & 641 & 614 & 892 & 527 & 431 & 223 \\
\hline & $6.04 \%$ & $11.52 \%$ & $18.47 \%$ & $8.80 \%$ & $9.24 \%$ & $11.83 \%$ & $22.01 \%$ & $11.40 \%$ & $14.04 \%$ & $6.51 \%$ \\
\hline \multirow{2}{*}{$\begin{array}{l}\text { Not avail for } \\
\text { employment }\end{array}$} & 46 & 77 & 8 & 452 & 298 & 274 & 93 & 166 & 132 & 159 \\
\hline & $6.04 \%$ & $3.09 \%$ & $3.21 \%$ & $4.08 \%$ & $4.30 \%$ & $5.28 \%$ & $2.30 \%$ & $3.59 \%$ & $4.30 \%$ & $4.65 \%$ \\
\hline \multirow[t]{2}{*}{ Other } & 4 & 21 & 5 & 164 & 117 & 152 & 55 & 66 & 51 & 40 \\
\hline & $0.52 \%$ & $0.84 \%$ & $2.01 \%$ & $1.48 \%$ & $1.69 \%$ & $2.93 \%$ & $1.36 \%$ & $1.43 \%$ & $1.66 \%$ & $1.17 \%$ \\
\hline \multirow[t]{2}{*}{ Explicit refusal } & 22 & 35 & 9 & 344 & 158 & 143 & 83 & 92 & 116 & 68 \\
\hline & $2.89 \%$ & $1.40 \%$ & $3.61 \%$ & $3.10 \%$ & $2.28 \%$ & $2.75 \%$ & $2.05 \%$ & $1.99 \%$ & $3.78 \%$ & $1.99 \%$ \\
\hline Total & 762 & 2,492 & 249 & 11,084 & 6,938 & 5,191 & 4,052 & 4,622 & 3,070 & 3,423 \\
\hline
\end{tabular}

Table 7: Distribution of graduates entering creative occupations and non-creative occupations across sub-disciplines with distinction based on London vs. outside London location 


\begin{tabular}{|c|c|c|c|c|c|c|}
\hline \multirow[b]{2}{*}{ Subject groups } & \multicolumn{2}{|c|}{ All } & \multicolumn{2}{|c|}{ London } & \multicolumn{2}{|c|}{ Outside of London } \\
\hline & $\begin{array}{c}\text { Non creative } \\
\text { occupation }\end{array}$ & $\begin{array}{c}\text { Creative } \\
\text { occupations }\end{array}$ & $\begin{array}{l}\text { Non creative } \\
\text { occupation }\end{array}$ & $\begin{array}{c}\text { Creative } \\
\text { occupations }\end{array}$ & $\begin{array}{c}\text { Non creative } \\
\text { occupation }\end{array}$ & $\begin{array}{c}\text { Creative } \\
\text { occupations }\end{array}$ \\
\hline \multirow[t]{2}{*}{ Non - bohemians } & 190,607 & 14,724 & 30,904 & 4,452 & 159,703 & 10,272 \\
\hline & $92.80 \%$ & $7.20 \%$ & $87.41 \%$ & $12.59 \%$ & $93.96 \%$ & $6.04 \%$ \\
\hline \multirow[t]{4}{*}{ Bohemians } & 19,037 & 11,476 & 3,652 & 3,798 & 15,385 & 7,678 \\
\hline & $62.40 \%$ & $37.60 \%$ & $49.02 \%$ & $50.98 \%$ & $66.71 \%$ & $33.29 \%$ \\
\hline & 338 & 253 & 52 & 85 & 286 & 168 \\
\hline & $57.19 \%$ & $42.81 \%$ & $37.96 \%$ & $62.04 \%$ & $63.00 \%$ & $37.00 \%$ \\
\hline \multirow[t]{2}{*}{ Architecture } & 376 & 1,606 & 63 & 478 & 313 & 1,128 \\
\hline & $18.97 \%$ & $81.03 \%$ & $11.65 \%$ & $88.35 \%$ & $21.72 \%$ & $78.28 \%$ \\
\hline \multirow[t]{2}{*}{ Crafts } & 128 & 42 & 1 & 4 & 127 & 38 \\
\hline & $75.29 \%$ & $24.71 \%$ & $20.00 \%$ & $80.00 \%$ & $76.97 \%$ & $23.03 \%$ \\
\hline \multirow[t]{2}{*}{ Design } & 4,873 & 3,275 & 854 & 1,071 & 4,019 & 2,204 \\
\hline & $59.81 \%$ & $40.19 \%$ & $44.36 \%$ & $55.64 \%$ & $64.58 \%$ & $35.42 \%$ \\
\hline \multirow[t]{2}{*}{$\begin{array}{l}\text { Film and } \\
\text { Television }\end{array}$} & 3,293 & 1,798 & 688 & 763 & 2,605 & 1,035 \\
\hline & $64.68 \%$ & $35.32 \%$ & $47.42 \%$ & $52.58 \%$ & $71.57 \%$ & $28.43 \%$ \\
\hline \multirow[t]{2}{*}{ Fine Art } & 2,746 & 802 & 508 & 205 & 2,238 & 597 \\
\hline & $77.40 \%$ & $22.60 \%$ & $71.25 \%$ & $28.75 \%$ & $78.94 \%$ & $21.06 \%$ \\
\hline \multirow[t]{2}{*}{ Music } & 1,932 & 789 & 354 & 254 & 1,578 & 535 \\
\hline & $71.00 \%$ & $29.00 \%$ & $58.22 \%$ & $41.78 \%$ & $74.68 \%$ & $25.32 \%$ \\
\hline \multirow[t]{2}{*}{$\begin{array}{r}\text { Performing } \\
\text { Arts }\end{array}$} & 2,346 & 1,122 & 509 & 418 & 1,837 & 704 \\
\hline & $67.65 \%$ & $32.35 \%$ & $54.91 \%$ & $45.09 \%$ & $72.29 \%$ & $27.71 \%$ \\
\hline \multirow[t]{2}{*}{ Technology } & 1,354 & 692 & 309 & 178 & 1,045 & 514 \\
\hline & $66.18 \%$ & $33.82 \%$ & $63.45 \%$ & $36.55 \%$ & $67.03 \%$ & $32.97 \%$ \\
\hline $\begin{array}{r}\text { Writing and } \\
\text { Publishing }\end{array}$ & 1,651 & 1,097 & 314 & 342 & 1,337 & 755 \\
\hline
\end{tabular}


$60.08 \%$

209,644

$88.89 \%$
$39.92 \%$

26,200

$11.11 \%$
$47.87 \%$

34,556

$80.73 \%$
$52.13 \%$

8,250

$19.27 \%$
$63.91 \%$

175,088

$90.70 \%$
$36.09 \%$

17,950

$9.30 \%$ 
Table 8: Mean (and median) salary across creative disciplines in creative and non-creative occupations

\begin{tabular}{|c|c|c|c|}
\hline \multirow[t]{2}{*}{ Subject } & \multicolumn{3}{|c|}{ Salary mean and (median) } \\
\hline & Non creative occupation & Creative occupations & All (rows) \\
\hline \multirow[t]{2}{*}{ Non - bohemians } & 20,963 & 21,413 & 20,995 \\
\hline & 19,000 & 19,000 & 19,000 \\
\hline \multirow[t]{2}{*}{ Bohemians } & 15,782 & 16,938 & 16,210 \\
\hline & 15,000 & 16,000 & 15,000 \\
\hline \multirow[t]{2}{*}{ Advertising } & 17,293 & 17,072 & 17,182 \\
\hline & 15,000 & 17,000 & 16,000 \\
\hline \multirow[t]{2}{*}{ Architecture } & 18,817 & 19,218 & 19,138 \\
\hline & 17,000 & 18,000 & 18,000 \\
\hline \multirow[t]{2}{*}{ Crafts } & 11,000 & 12,614 & 11,217 \\
\hline & 11,000 & 12,000 & 11,000 \\
\hline Design & 15,163 & 16,289 & 15,610 \\
\hline \multirow[t]{2}{*}{ Film \& TV } & 14,449 & 15,997 & 15,028 \\
\hline & 13,000 & 15,000 & 14,000 \\
\hline \multirow[t]{2}{*}{ Fine Art } & 16,077 & 13,761 & 15,739 \\
\hline & 17,000 & 13,000 & 16,000 \\
\hline \multirow[t]{2}{*}{ Music } & 16,484 & 15,628 & 16,249 \\
\hline & 16,000 & 15,000 & 16,000 \\
\hline \multirow[t]{2}{*}{ Performing Arts } & 14,886 & 14,978 & 14,912 \\
\hline & 14,000 & 15,000 & 14,000 \\
\hline \multirow[t]{2}{*}{ Technology } & 17,638 & 20,162 & 18,547 \\
\hline & 16,000 & 19,000 & 17,000 \\
\hline \multirow[t]{2}{*}{ Writing and Publishing } & 17,358 & 17,717 & 17,498 \\
\hline & 16,000 & 16,000 & 16,000 \\
\hline
\end{tabular}




\begin{tabular}{|l|l|l|l|}
\hline Totals & 20,581 & 19,734 & 20,490 \\
\hline & 19,000 & 18,000 & 19,000 \\
\hline
\end{tabular}

Table 9: Creative occupation as share of jobs across UK regions (with share of Total UK Labour force of the region)

\begin{tabular}{|c|c|c|c|c|}
\hline Region of job & $\begin{array}{r}\text { All } \\
\text { Graduates }\end{array}$ & $\begin{array}{r}\text { Non-creative } \\
\text { occupations }\end{array}$ & $\begin{array}{r}\text { Creative } \\
\text { occupations }\end{array}$ & $\begin{array}{r}\text { Share of Total UK } \\
\text { Labour Force }\end{array}$ \\
\hline London & 19.24 & 17.42 & 34.21 & 12.80 \\
\hline South East & 12.44 & 12.40 & 12.77 & 14.05 \\
\hline North West & 10.86 & 11.16 & 8.39 & 11.04 \\
\hline Scotland & 9.35 & 9.67 & 6.66 & 8.56 \\
\hline Yorkshire and The Humber & 7.94 & 8.17 & 6.03 & 8.46 \\
\hline West Midlands & 7.62 & 7.86 & 5.70 & 8.66 \\
\hline South West & 7.41 & 7.44 & 7.14 & 8.39 \\
\hline East of England & 6.83 & 6.93 & 6.07 & 9.32 \\
\hline East Midlands & 6.04 & 6.21 & 4.63 & 7.41 \\
\hline Wales & 4.81 & 4.99 & 3.32 & 4.58 \\
\hline North East & 4.16 & 4.30 & 2.95 & 4.08 \\
\hline Northern Ireland & 3.30 & 3.44 & 2.13 & 2.65 \\
\hline Total & 100 & 100 & 100 & 100 \\
\hline
\end{tabular}


Table 10: Distribution of graduates in creative occupations across the UK region (\%)

\begin{tabular}{|c|c|c|c|c|c|c|c|c|c|c|c|c|c|}
\hline $\begin{array}{l}\text { Region } \\
\text { of } \\
\text { employ } \\
\text { ment }\end{array}$ & $\begin{array}{l}\text { Non- } \\
\text { bohemi } \\
\text { an }\end{array}$ & $\begin{array}{c}\text { Bohemi } \\
\text { an }\end{array}$ & $\%$ Adv & $\%$ Arch & $\%$ Crafts & $\begin{array}{c}\% \\
\text { Design }\end{array}$ & $\begin{array}{c}\text { \% Film \& } \\
\text { TV }\end{array}$ & $\begin{array}{c}\% \text { Fine } \\
\text { Art }\end{array}$ & \% Music & $\begin{array}{c}\% \text { Perf } \\
\text { Arts }\end{array}$ & $\%$ Techn & $\begin{array}{c}\% \\
\text { Writing } \\
\text { \& Publ }\end{array}$ & All \\
\hline GL & 32.49 & 36.48 & 36.96 & 31.39 & 10.53 & 35.46 & 45.94 & 27.67 & 41.10 & 44.00 & 27.94 & 34.48 & 34.21 \\
\hline SE & 14.16 & 10.93 & 6.96 & 9.13 & 18.42 & 10.53 & 11.50 & 13.90 & 10.84 & 8.74 & 19.31 & 9.17 & 12.77 \\
\hline NW & 8.13 & 8.74 & 6.96 & 9.91 & 10.53 & 8.94 & 7.16 & 7.96 & 10.68 & 9.47 & 7.85 & 8.57 & 8.39 \\
\hline SW & 6.80 & 7.59 & 6.09 & 7.29 & 10.53 & 7.55 & 7.83 & 12.69 & 5.34 & 5.68 & 7.38 & 7.56 & 7.14 \\
\hline $\mathrm{YH}$ & 5.93 & 6.16 & 8.70 & 6.96 & 13.16 & 5.43 & 5.18 & 5.94 & 2.91 & 6.11 & 11.46 & 6.75 & 6.03 \\
\hline EM & 4.75 & 4.47 & 8.26 & 4.14 & 5.26 & 6.42 & 3.55 & 4.18 & 2.43 & 2.63 & 2.04 & 4.44 & 4.63 \\
\hline SCT & 6.44 & 6.95 & 13.48 & 11.95 & 10.53 & 4.83 & 3.43 & 9.18 & 8.25 & 5.79 & 5.49 & 9.58 & 6.66 \\
\hline WM & 5.90 & 5.43 & 1.30 & 4.99 & 15.79 & 6.32 & 5.72 & 4.86 & 5.83 & 4.11 & 5.34 & 4.94 & 5.70 \\
\hline WA & 3.07 & 3.65 & 2.61 & 3.15 & 2.63 & 3.74 & 2.29 & 3.10 & 3.72 & 5.05 & 4.87 & 4.94 & 3.32 \\
\hline $\mathrm{EE}$ & 6.69 & 5.24 & 5.22 & 4.53 & 0.00 & 6.59 & 4.82 & 5.26 & 5.99 & 5.68 & 2.83 & 3.83 & 6.07 \\
\hline NE & 3.28 & 2.52 & 1.74 & 2.82 & 2.63 & 3.01 & 1.99 & 3.37 & 2.27 & 1.68 & 1.10 & 2.82 & 2.95 \\
\hline
\end{tabular}




\begin{tabular}{|l|r|r|r|r|r|r|r|r|r|r|r|r|r|r|}
\hline $\mathrm{NI}$ & $\mathbf{2 . 3 6}$ & $\mathbf{1 . 8 3}$ & 1.74 & 3.74 & 0.00 & 1.16 & 0.60 & 1.89 & 0.65 & 1.05 & 4.40 & 2.92 & 2.13 & \\
\hline & 100 & 100 & 100 & 100 & 100 & 100 & 100 & 100 & 100 & 100 & 100 & 100 & 100 \\
\hline
\end{tabular}

Table 11: Earning equations (Dependent Variable: LogSalary)

\begin{tabular}{|c|c|}
\hline & Ln(salary) \\
\hline \multicolumn{2}{|c|}{ Personal Characteristics } \\
\hline \multirow[t]{2}{*}{ Female } & $-0.034 * * *$ \\
\hline & {$[-4.06]$} \\
\hline \multicolumn{2}{|c|}{ Age on graduation (ref: 21 and under) } \\
\hline \multirow[t]{2}{*}{$22-24$} & $0.034 * * *$ \\
\hline & {$[3.70]$} \\
\hline \multirow[t]{2}{*}{$25+$} & $0.135^{* * *}$ \\
\hline & {$[9.04]$} \\
\hline \multirow[t]{2}{*}{ Disabled } & 0.006 \\
\hline & {$[0.39]$} \\
\hline \multicolumn{2}{|c|}{ Ethnicity (ref: white) } \\
\hline \multirow[t]{2}{*}{ Black } & $0.055^{*}$ \\
\hline & [1.92] \\
\hline \multirow[t]{2}{*}{ Asian } & 0.027 \\
\hline & [1.36] \\
\hline \multirow[t]{2}{*}{ Mixed } & -0.008 \\
\hline & {$[-0.28]$} \\
\hline \multirow[t]{2}{*}{ Other } & $-0.113^{*}$ \\
\hline & {$[-1.87]$} \\
\hline \multicolumn{2}{|c|}{ Degree classification (ref: Upper second) } \\
\hline \multirow[t]{2}{*}{ First } & 0.005 \\
\hline & {$[0.33]$} \\
\hline
\end{tabular}

\begin{tabular}{|c|c|}
\hline \multirow[t]{2}{*}{ Lower second } & $-0.029 * * *$ \\
\hline & {$[-3.33]$} \\
\hline \multirow[t]{2}{*}{ Third/pass } & $-0.029 *$ \\
\hline & {$[-1.77]$} \\
\hline \multirow[t]{2}{*}{ Other degree class } & -0.005 \\
\hline & {$[-0.18]$} \\
\hline \multicolumn{2}{|c|}{ Institution Type (ref: New University) } \\
\hline \multirow[t]{2}{*}{ Russell group } & -0.015 \\
\hline & {$[-0.91]$} \\
\hline \multirow[t]{2}{*}{ Other old } & $0.023^{*}$ \\
\hline & {$[1.86]$} \\
\hline \multirow[t]{2}{*}{ HE/FE Colleges } & $-0.040 * * *$ \\
\hline & {$[-3.61]$} \\
\hline \multicolumn{2}{|c|}{ Creative graduate (ref: Design) } \\
\hline \multirow[t]{2}{*}{ Advertising } & $0.049 * *$ \\
\hline & {$[2.30]$} \\
\hline \multirow[t]{2}{*}{ Architecture } & 0.005 \\
\hline & [0.27] \\
\hline \multirow[t]{2}{*}{ Crafts } & -0.066 \\
\hline & {$[-1.02]$} \\
\hline \multirow[t]{2}{*}{ Film and Television } & 0.01 \\
\hline & {$[0.87]$} \\
\hline Fine Art & $-0.033^{*}$ \\
\hline
\end{tabular}




\begin{tabular}{|l|l|}
\hline & {$[-1.85]$} \\
\hline Music & -0.014 \\
\hline & {$[-0.66]$} \\
\hline Performing Arts & 0.005 \\
\hline & {$[0.35]$} \\
\hline Technology & $0.081^{* * *}$ \\
\hline & {$[4.99]$} \\
\hline Writing and Publishing & $0.048^{* * *}$ \\
\hline & {$[3.42]$} \\
\hline Job Attributes (ref: Full-time) & \multicolumn{2}{|l}{} \\
\hline Part time & $-0.395^{* * *}$ \\
\hline & {$[-21.2]$} \\
\hline Freelance/self employed & $-0.107^{* * *}$ \\
\hline & {$[-3.15]$} \\
\hline Region of Job (ref: South East) & \multicolumn{2}{|l}{} \\
\hline North East & $-0.086^{* * *}$ \\
\hline & {$[-4.75]$} \\
\hline North West & $-0.068^{* * *}$ \\
\hline & {$[-4.40]$} \\
\hline Yorkshire \& Humberside & $-0.113^{* * *}$ \\
\hline & {$[-6.48]$} \\
\hline East Midlands & $-0.068^{* * *}$ \\
\hline & {$[-3.81]$} \\
\hline & \\
\hline &
\end{tabular}

\begin{tabular}{|l|l|}
\hline West Midlands & $-0.063^{* * *}$ \\
\hline & {$[-3.71]$} \\
\hline East of England & -0.013 \\
\hline & {$[-0.78]$} \\
\hline London & $0.121^{* * *}$ \\
\hline & {$[9.62]$} \\
\hline South West & $-0.083^{* * *}$ \\
\hline & {$[-4.89]$} \\
\hline Wales & $-0.049^{* *}$ \\
\hline & {$[-2.48]$} \\
\hline Scotland & $-0.070^{* * *}$ \\
\hline & {$[-2.97]$} \\
\hline Northern Ireland & $-0.153^{* * *}$ \\
\hline & {$[-4.99]$} \\
\hline & \\
\hline Constant & $9.459^{* * *}$ \\
\hline & {$[434]$} \\
\hline Observations & 7,749 \\
\hline r-squared & 0.35 \\
\hline Robust t statistics in brackets & \\
\hline$* * * p<0.01, * * p<0.05, * 0.1$ & \\
\hline Also includes controls for industry and sOC group \\
\hline
\end{tabular}


Appendix 1

\begin{tabular}{|c|c|}
\hline $\begin{array}{l}\text { Creative Sub- } \\
\text { disciplines }\end{array}$ & JACS codes \\
\hline Architecture & $\begin{array}{l}\text { K Architecture, Building and Planning; K100 Architecture; K110 Architectural Design } \\
\text { Theory; K120 Interior Architecture; K130 Architectural Technology; K190 } \\
\text { Architecture not elsewhere classified; K300 Landscape Design; K310 } \\
\text { Landscape Architecture; K320 Landscape studies; K390 Landscape Design not } \\
\text { elsewhere classified }\end{array}$ \\
\hline Advertising & $\begin{array}{l}\text { N561 Advertising; P200 Publicity studies; P210 Public Relations; P290 Publicity } \\
\text { studies not elsewhere classified }\end{array}$ \\
\hline Crafts & $\begin{array}{l}\text { W700 Crafts; W710 Fabric and Leather Crafts; W711 Needlecraft; W712 } \\
\text { Dressmaking; W713 Soft Furnishing; W714 Weaving; W715 Leatherwork; W720 } \\
\text { Metal Crafts; W721 Silversmithing / Goldsmithing; W722 Blacksmithing; W723 } \\
\text { Clock/Watchmaking; W730 Wood Crafts; W731 Carpentry/Joinery; W732 Cabinet } \\
\text { making; W733 Marquetry and Inlaying; W734 Veneering; W740 Surface } \\
\text { Decoration; W750 Clay and Stone Crafts; W751 Pottery; W75 Tile Making; W753 } \\
\text { Stone Crafts; W760 Reed Crafts; W761 Basketry; W762 Thatching; W770 Glass } \\
\text { Crafts; W771 Glassblowing; W780 Paper Crafts; W781 Bookbinding; W782 } \\
\text { Origami; W790 Crafts not elsewhere classified }\end{array}$ \\
\hline Design & $\begin{array}{l}\text { W200 Design studies; W210 Graphic Design; W211 Typography; W212 } \\
\text { Multimedia Design; W213 Visual Communication; W220 Illustration; W230 } \\
\text { Clothing/Fashion Design; W231 Textile Design; W240 Industrial/Product Design; } \\
\text { W250 Interior Design; W260 Furniture Design; W270 Ceramics Design; W990 } \\
\text { Creative Arts and Design not elsewhere classified }\end{array}$ \\
\hline Film and TV & $\begin{array}{l}\text { P300 Media studies; P301 Television studies; P302 Radio studies; P303 Film } \\
\text { studies; P304 Electronic Media studies; P310 Media Production; P311 Television } \\
\text { Production; P312 Radio Production; P313 Film Production; P390 Media studies } \\
\text { not elsewhere classified; W600 Cinematics and Photography; W610 Moving Image } \\
\text { Techniques; W611 Directing Motion Pictures; W612 Producing Motion Pictures; } \\
\text { W613 Film \& Sound Recording; W614 Visual and Audio Effects; W620 } \\
\text { Cinematography; W630 History of Cinematics and Photography; W631 History of } \\
\text { Cinematics; W632 History of Photography; W640 Photography; W690 Cinematics } \\
\text { and Photography not elsewhere classified }\end{array}$ \\
\hline Fine Arts & $\begin{array}{l}\text { P130 Curatorial studies; P131 Museum studies; P132 Archive studies; W100 Fine } \\
\text { Art; W110 Drawing; W120 Painting; W130 Sculpture; W140 Printmaking; W150 } \\
\text { Calligraphy; W160 Fine Art Conservation; W190 Fine Art not elsewhere classified; } \\
\text { W900 Others in Creative Arts and Design }\end{array}$ \\
\hline Music & $\begin{array}{l}\text { W300 Music; W310 Musicianship/Performance studies; W330 History of Music; } \\
\text { W340 Types of Music; W350 Musicology; W360 Musical Instrument History; W390 }\end{array}$ \\
\hline
\end{tabular}




\begin{tabular}{|l|l|}
\hline Technology & $\begin{array}{l}\text { Music not elsewhere classified } \\
\text { Electronic Design; W615 Animation Techniques; G450 Multi-media Computing } \\
\text { Science; G600 Software Engineering; G610 Software Design; J931 Music } \\
\text { Recording; J950 Musical Instrument Technology; P412 Publishing on CD-ROM; } \\
\text { P413 Publishing via the World Wide Web }\end{array}$ \\
\hline $\begin{array}{l}\text { Performing } \\
\text { Arts }\end{array}$ & $\begin{array}{l}\text { W400 Drama; W410 Acting; W420 Directing for Theatre; W430 Producing for } \\
\text { Theatre; W440 Theatre studies; W450 Stage Management; W451 Theatrical } \\
\text { Wardrobe Design; W452 Theatrical Make-up; W460 Theatre Design; W461 Stage } \\
\text { Design; W490 Drama not elsewhere classified; W500 Dance; W510 Choreography; } \\
\text { W520 Body Awareness; W530 History of Dance; W540 Types of Dance; W590 } \\
\text { Dance not elsewhere classified }\end{array}$ \\
\hline $\begin{array}{l}\text { Writing and } \\
\text { Publishing }\end{array}$ & $\begin{array}{l}\text { P100 Information Services; P110 Information Management; P120 Librarianship; } \\
\text { P121 Library studies; P190 Information Services not elsewhere classified P490 } \\
\text { Publishing not elsewhere classified; P500 Journalism; P510 Factual Reporting; P590 } \\
\text { Journalism not elsewhere classified; P900 Others in Mass Communications and } \\
\text { Documentation; P990 Mass Communications and Documentation not elsewhere } \\
\text { classified; P400 Publishing; P410 Electronic Publishing; P411 Publishing on } \\
\text { audio/video tape; P305 Paper-based Media studies; W800 Imaginative Writing; } \\
\text { W810 Scriptwriting; W820 Poetry Writing; W830 Prose Writing; W890 Imaginative } \\
\text { Writing not elsewhere classified. }\end{array}$ \\
\hline
\end{tabular}




\footnotetext{
' For a summary of his speech see URL: http://www.campaignlive.co.uk/news/899097/Digital-Britain-SummitGordon-Brown-pledges-support-creative-industries/ (last accessed 20 June 2010).

ii The flagship New Labour's arts education project might be one of the victims of funding cuts planned by the new coalition government.

iii In the review, it is specifically stated "there are many excellent examples of collaborations involving the creative industries and universities or colleges of art and design. Policy-makers must ensure that policies aimed at promoting knowledge transfer are broad enough to allow initiatives such as these to grow and flourish, and that the focus is not entirely on science and engineering" HM Treasury 2003, p. 43

iv Million + (formerly known as the Coalition of Modern Universities) is a think-tank membership organisation mainly involving post-1992 and university colleges.

${ }^{v}$ For more information on the Joint Academic Coding System (or JACS) see http://www.hesa.ac.uk/index.php?option=com content\&task=view\&id=158\&ltemid=233
}

${ }^{\mathrm{vi}}$ Although six months may seem relatively early on in graduate careers, it is still a useful indicator of both longer term labour market success (Elias et al., 1999) and assimilation into the graduate labour market. Elias et al. (1999) found that students employed six months after graduation were more likely to be in graduate jobs three and half years later, while graduates unemployed six months after leaving university tended to have lower earnings and lower job satisfaction later on in their careers (McKnight, 1999).

vii We acknowledge that this definition has quite a few limitations (see for further discussion Oakley, 2006) and might not be applicable to other countries but considering that our analysis is set in the UK, this is seems to be the most suitable definition to adopt. Therefore, it is important to clarify that 'creative occupations' here are not defined as occupations that are creative (this could include for instance scientific inventions and other creative jobs) but as occupation within the creative (and cultural) sector as defined by the DCMS.

viii Graduates were categorised as 'bohemian graduates' if they were a single honours students and their subject fell under any of the creative categories; if they were a joint honours student and their first or both subjects were creative - those whose second but not first subject were classed as bohemian were classified as "non-bohemian"; if they were a joint honours student with three subjects and two or three of the subjects were creative (even if the first subject was not creative).

ix Comunian et al. (2010) acknowledges the difficulties and limitations in connecting the mainly UK-based literature on creative industries, with broader US-based argument (Florida, 2002c) about the role of 'bohemians' in regional economic development. Therefore, the definition adopted here is not meant to categorise students as 'bohemian' in reference to a presumed 'artistic lifestyle' (other students in other disciplines might be pursuing this sort of lifestyle) again non-bohemians. It is meant to associate the professions which are defined by Florida (2002c) as 'bohemian' and which in UK are closely correspondents to the creative industries with the HE disciplines that broadly corresponds to those fields. For an extensive discussion see Comunian et al., 2010

${ }^{x}$ The following guidelines have been used in the classification in creative sub groupings. If the student had more than one subject that was creative the first subject's sub group was used. When the student was studying three subjects the second subject was used if the first subject was non-creative.

${ }^{x i}$ Note the model only refers to undergraduates since it includes degree classification.

xii We acknowledge the suggestion of one of our referees of the need to reflect on the overall role of a degree in this field of study / work. 